\title{
A mitralis elégtelenség sebészi kezelésének új megközelítése: transapicalis ínhúrpótlás dobogó szíven*
}

\author{
Ruttkay Tamás dr. ${ }^{1,2}$ - Jancsó Gábor dr. ${ }^{1}$ \\ Gombocz Károly dr. ${ }^{3}$. Gasz Balázs dr. ${ }^{1,3}$ \\ ${ }^{1}$ Pécsi Tudományegyetem, Általános Orvostudományi Kar, Sebészeti Oktató és Kutató Intézet, Pécs \\ ${ }^{2}$ Sana Herzchirurgie Stuttgart GmbH, Stuttgart \\ ${ }^{3}$ Zala Megyei Kórház, Szívsebészeti Osztály, Zalaegerszeg
}

\begin{abstract}
A mitralis billentyü prolapsusa következtében fennálló súlyos billentyúelégtelenség mielőbbi sebészi kezelése szükséges. A modern korrekció során az ínhúrpótlás részesítendő előnyben, amely mútéthez azonban jelenleg a szív megállítása és extracorporalis keringés alkalmazása szükséges a bal pitvar megnyitása mellett. A transoesophagealis szívultrahanggal vezérelt transapicalis ínhúrpótlás innovatív technikája egy speciális, bal kamrába vezetett eszköz használatával bal oldali minithoracotomián keresztül dobogó szíven végezhető. A beavatkozások során elért intraoperatív siker aránya centrumonként 86 és 100\% között változik, és egyes közlemények szerint 3 hónap elteltével a betegek 92\%-ának nincs szüksége újabb sebészi korrekcióra. A tapasztalatok folyamatos integrálásának köszönhető biztató eredmények a jelentősen kisebb műtéti megterhelés lehetőségét ígérő technika széles körû elterjedésének irányába mutatnak. Orv. Hetil., 2016, 157(18), 700-705.
\end{abstract}

Kulcsszavak: mitralis billentyü, chordae tendineae, szívsebészeti beavatkozás, minimálisan invazív sebészet

\section{New approach in the surgical treatment of mitral regurgitation: beating heart transapical neochord implantation}

Severe mitral regurgitation due to prolapse of the valve demands early surgical intervention. Recently artificial chord implantation is the prefered solution, which requires cardioplegia and application of cardiopulmonary bypass using the left atrial approach. Transoesophageal echocardiography guided transapical neochord implantation is an emerging new technique for the treatment of mitral regurgitation. It enables the operation through left minithoracotomy on beating heart using a special instrument introduced into the left ventricle. Acute procedural success rates in different centres vary between 86 and 100\%. According to reports, $92 \%$ of the patients do not require additional intervention at the 3-month follow-up. Continuous integration of data resulting improved outcomes supports the hope that this novel, less-invasive technique will be applied widely for the treatment of mitral regurgitation.

Kulcsszavak: mitral valve, chordae tendineae, cardiac surgical procedures, minimally invasive surgery

Ruttkay, T., Jancsó, G., Gombocz, K., Gasz, B. [New approach in the surgical treatment of mitral regurgitation: beating heart transapical neochord implantation]. Orv. Hetil., 2016, 157(18), 700-705.

(Beérkezett: 2016. január 14.; elfogadva: 2016. február 18.)

*A Dr. Fehér János Emlékére Alapítvány 2016. évi pályázatán díjazott dolgozat. 


\section{A mitralis elégtelenség etiológiája}

A mitralis billentyű elégtelensége etiológia alapján két nagy csoportra osztható. Megkülönböztetünk funkcionális és organikus elégtelenséget. A funkcionális elégtelenség a bal kamra patológiás morfológiája, illetve funkciója következtében alakul ki egészséges billentyüstruktúrák (vitorlák, inhúrok, papillaris izmok) mellett, többnyire a mitralis anulus dilatációjának eredményeként. Ilyen esettel találkozunk többek között dilatatív vagy ischaemiás cardiomyopathiánál. Az organikus elégtelenség esetében a billentyústruktúrák patológiás elváltozásai eredményeznek insufficientiát. A legtöbbször megjelenő ilyen patológiás elváltozás a vitorlák prolapsusa az ínhúrok megnyúlásának vagy szakadásának következtében $[1,2]$. A prolapsus döntő többségében a hátsó vitorla $\mathrm{P} 2$-szegmentumát érinti $[3,4]$.

\section{A mitralis elégtelenség modern kezelési stratégiája}

A mitralis elégtelenség modern sebészi kezelésében a billentyưmegtartó beavatkozások kapnak főszerepet. A beteg érdekét a saját billentyüjének operatív rekonstrukciója szolgálja. A különböző etiológiájú elégtelenségek mưtéti kockázata, illetve túlélése eltérô. A magasabb rizikójú, döntően funkcionális mitralis elégtelenséggel küzdő betegek modern invazív kardiológiai eljárásokkal való kezelése - mint például a hazánkban is elérhető MitraClip-beültetés - kitűnő középtávú eredményeket mutat [5]. Az organikus billentyüelégtelenség sebészi rekonstrukciós módszereinek fejlődése során szintén számos újí- tás javította időről időre az eredményeket. A széles körű nemzetközi szakirodalom alapján a mútéti korrekció mielőbb elvégzendő, és a billentyüplasztika az esetek 9599\%-ában kuratív és hosszú távon is eredményes [6].

Az anuloplasztika során csaknem minden esetben beültetésre kerül egy, a billentyứk különböző patológiás elváltozásainak megfelelően kialakított rigid vagy szemirigid gyürü. A sikerrel alkalmazott triangularis vagy quadrangularis reszekció során a vitorla patológiás részlete háromszög, illetve trapéz alakban kimetszésre, a szélek pedig tovafutó varrattal egyesítésre kerülnek [7]. Ezt a technikai megoldást ma már egyre inkább kiváltja az egészséges billentyü struktúráját leginkább helyreállító módszer, a leszakadt és megnyúlt ínhúrok pótlása $[8,9]$. A leírt kiváló eredményeket mutató rekonstrukciós, billentyưmegtartó technikák mindegyike bal pitvar felőli feltárásból végzendő. A kisebb mütéti terhelés érdekében a medián sternotomia mellett megjelent ugyan a jobb oldali minithoracotomia és az intraoperatív endoszkópos képalkotás, azonban ebben az esetben sem nélkülözhető az extracorporalis keringés alkalmazása és a szív megállítása [10].

Összegezve a mitralis billentyű prolapsusának ideális rekonstrukciós stratégiájának sarokpontjait, egy olyan módszerre van szükség, amely megbízható ínhúrpótlást tesz lehetővé egyszerűen kivitelezhető feltárásból dobogó szíven extracorporalis keringés alkalmazása és annak káros patofiziológiai hatásai nélkül. A politetrafluoroetilén ínhúrok beültetése nagyon jó hosszú távú eredményeket mutat. A mitralis billentyú szívcsúcsi endoszkópos nézetének tanulmányozása kapcsán munkacsoportunk arra a következtetésre jutott, hogy a szív-

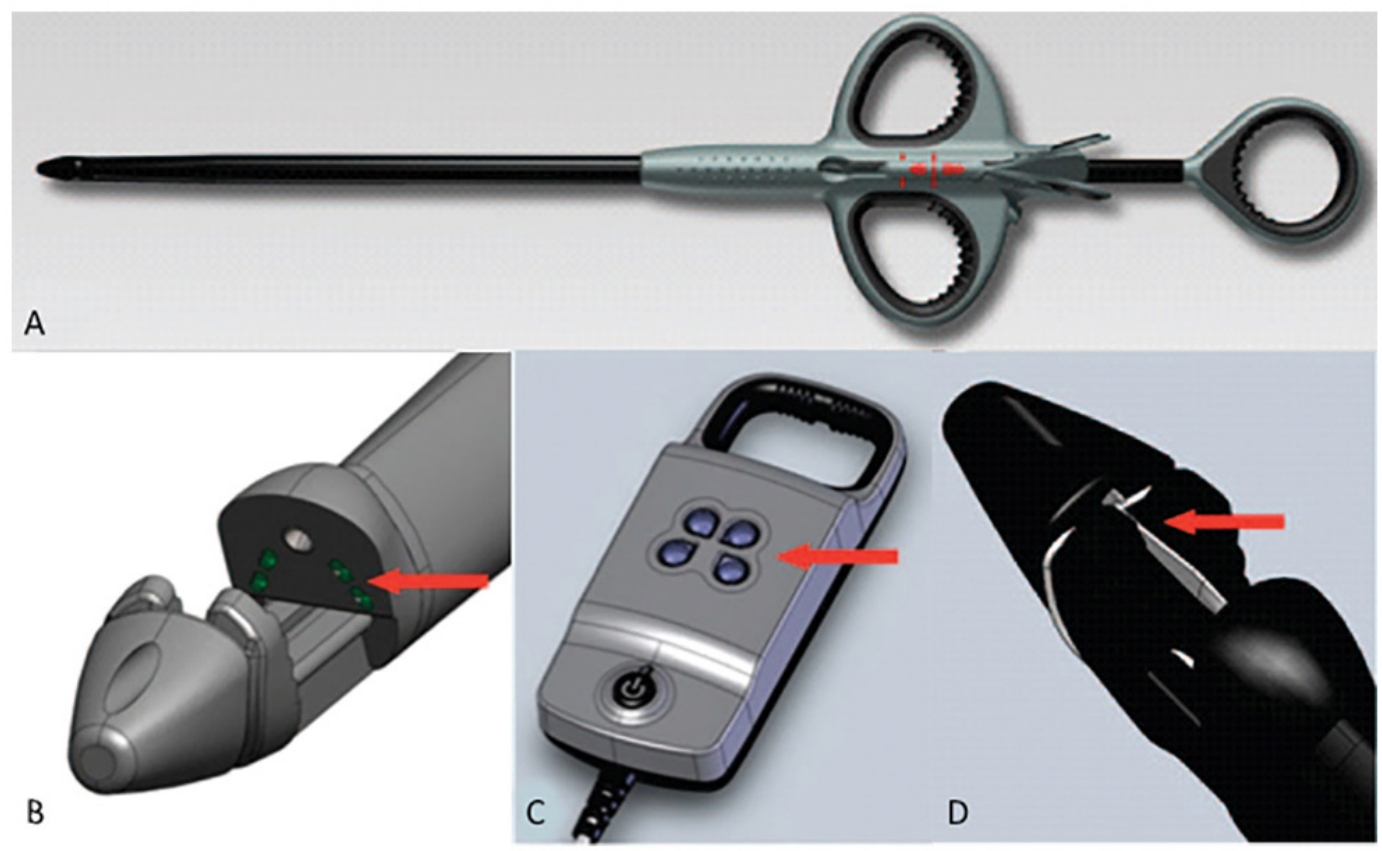

1. ábra

A NeoChord DS1000 transapicalis inhúrpótló eszköz (A) a következő részeket tartalmazza: a csúcsi rész (B) a vitorla szélének optimális megragadására szolgál és magába foglalja a fiberoptikai érzékelőket, amelyek a jelzőkészülék (C) lámpáihoz továbbítják az információt. A billentyü átöltésére szolgáló tű (D) négy fehér jelzőfény felvillanása esetén oldandó ki (Forrás: http://www.neochord.com/index.php/neochord-ds1000) 
csúcs felől az anatómiai struktúrák hozzáférhetősége és vizualizálása egyaránt kitűnő [1 1, 12], illetve ez az apicalis feltárás mára a katéteres aortabillentyü-beültetések rutinszerúen használt biztonságos behatolási pontjának számít [13]. A korszerû echokardiográfiás képalkotás lehetővé tette a bal kamra képleteinek valós idejű háromdimenziós ábrázolását. A modern technikai lehetőségek segítségével a felsorolt elvárásokat teljesíti a mitralis billentyú prolapsusának kezelésére alkalmas legújabb módszer, a szívcsúcs felőli ínhúrpótlás. Célunk a sokrétű előnyöket ígérő forradalmi technika lépésről lépésre való leírása, illetve az aktuálisan elérhetô klinikai vizsgálati eredmények ismertetése.

\section{A transapicalis ínhúrpótlás technikája}

Az ínhúrpótlás precíz kivitelezéséhez kétdimenziós és háromdimenziós transoesophagealis szívultrahang vezérlete szükséges $[14,15]$. Az echokardiográfiás képalkotás mind a mütét előtti részletes tervezés, mind az intraoperatív vezérlés, mind a mütét utáni eredmény dokumentálása során nélkülözhetetlen.

A feltárásként használt bal anterolateralis minithoracotomia 4-5 cm-es metszése az ötödik bordaközben ejtendő. Az ínhúrpótló eszköz (NeoChord ${ }^{\odot}$ DS1000, NeoChord Inc., Minneapolis, Minnesota) (1. ábra) kifejlesztése során nagy hangsúlyt fektettek a mitralis vitorla megbízható megragadására. Ezért a rendszer két, vezetékkel összekapcsolt fő komponensból áll, a beültetésre alkalmas eszközből és egy, a billentyű megfelelő átöltését segítő jelzőkészülékből. Az optimális transmuralis metszés döntően a szívcsúcstól $2-4 \mathrm{~cm}$-re posterolateralisan helyezkedik el. A helyes metszési pozíció az operatőr ujja benyomatának multiplan echokardiográfiás megjelenítésével meghatározható. Ezt követően az eszköz lándzsaszerü része ( $8 \mathrm{~mm}$ átmérő, $24 \mathrm{~F}$ ) bevezetésre kerül a bal kamrába, illetve bal pitvarba. A szíven belüli mozgásokat, valamint a vitorla megragadását az operatőr egy fogantyús nyéllel kontrollálja. A szív üregébe vezetett rész két csatornát tartalmaz. Az egyikben egy, a billentyúvitorla marginális részének átöltésére alkalmas szigony alakú tû helyezkedik el, a másik pedig egy politetrafluoroetilén fonal hurkát tartalmazza. Ebben a lándzsaszerű részben található egy négycsatornás fiberoptikai érzékelő is, amely azokat közrefogva különbséget tesz vér és billentyû között. A szívultrahangos vizsgáló ráközelít a bevezetett müszerre, hogy a multiplan kétdimenziós, valamint a háromdimenziós képalkotás segítségével közvetlenül vizualizálható legyen annak pontos helyzete a vitorlákhoz. A vitorla megragadása során a tü körül elhelyezkedő négy optikai csatorna szolgáltat információt az ínhúrpótló eszköz másik nagy komponensének, a kijelzőnek. A kijelzőn található négy pont pirosan világít, amennyiben a bevezetett eszköznek nincs közvetlen kapcsolata a billentyúvel. Amennyiben a vitorla megragadása sikeres, tehát az érzékelők között a vitorla helyezkedik el, akkor fehéren világító pontok láthatók a kijelzőn. Optimális esetben mind a négy pont fehér, és az ínhúr átöltése a vitorla szélétől $3-4 \mathrm{~mm}$-re várható. Két fehér és két piros pont felvillanása esetén nincs megfelelő mennyiségű billentyưszövet az érzékelők között és újrapozicionálás szükséges. Megfelelő pozíció esetén, a fonal átöltése után, a szigonyszerü tûvel a szívcsúcson keresztül kihúzott fonal hurkot képez és rögzül a prolabáló vitorla széli részén. Az operatőr ezután a mitralis elégtelenség valós idejü color Doppler megjelenítése mellett húzást gyakorol a beültetett ínhúrra. Így a szívcsúcson kivezetett fonal optimális, billentyúelégtelenséget hatékonyan kezelő hosszúsága beállítható és ebben a pozícióban teflonfolttal megerősített öltéssel rögzíthető. Az eszköz alkalmas mind az elülső, mind a hátsó mitralis vitorla prolapsusának kezelésére. Az esetek döntő többségében több ínhúr egyidejü beültetése szükséges az ideális eredmény elérése érdekében.

\section{A klinikai vizsgálatok eredményei}

A dobogó szíven végzett transapicalis ínhúrpótlás technikájának kifejlesztése után biztató állatkísérletes eredmények születtek [16-18], amelyek alapján a módszer klinikai alkalmazására kerülhetett sor. Az esettanulmányokon [19-23] kívüli négy releváns klinikai vizsgálatból született publikáció által leírt adatokat foglaljuk össze.

Az első vizsgálatot 7 centrum (Lipcse, München, Bad Nauheim, Torino, Milánó, Aarhus, Vilnius) bevonásával 30 konvencionális mútétre tervezett betegen végezték [24]. Az indikáció minden esetben súlyos organikus mitralis elégtelenség volt a hátsó vitorla anulodilatáció nélküli prolapsusának következtében. Kizáró kritériumok között a funkcionális billentyúelégtelenség, az elülső vitorla vagy mindkét vitorla prolapsusa, a súlyos bal kamrai funkciózavar, a permanens pitvarfibrilláció és az egyéb szívmütéti indikáció szerepelt. A vizsgálat során két ponton volt szükség a módszer finomítására. Két beteg után már minden esetben egynél több ínhúr került beültetésre, valamint tizenöt mütét után csak posterolateralis szívcsúcsi behatolást végeztek.

Intraoperatív sikerként a mitralis elégtelenség legalább másodfokúra való redukcióját határozták meg. A második modifikációval (posterolateralis szívcsúcsi behatolás) operált páciensek körében a primer siker 100\%-os volt. Az összes beteg közül primer sikert 26 (86,7\%) esetben sikerült elérni. Négy betegnél pedig technikai vagy betegspecifikus okból az ínhúrpótlás egyáltalán nem volt lehetséges. Összesen 8 betegnél került sor azonnali vagy néhány nappal későbbi sikeres konvencionális mitralisbillentyü-plasztikára, ugyanis további 4 beteg esetében billentyüsérülés jött létre.

A 30. posztoperatív napon történt vizsgálat során 17 $(58,6 \%)$ esetben találtak optimális eredményt legfeljebb másodfokú billentyúelégtelenséggel, amiből 12 betegnek legfeljebb elsőfokú elégtelensége volt.

A beavatkozások során minden beteg hemodinamikailag stabil maradt. A 30 betegból egy szenvedett el minor 
stroke-ot 30 napon belüli teljes felépüléssel. Hosszabb posztoperatív lélegeztetés csak ugyanennél a betegnél volt szükséges, a betegek döntő többségét 3 órán belül extubálták. Egy 82 éves multimorbid nőbeteg a 4. posztoperatív napon visszatérő súlyos mitralis elégtelenség, postcardiotomiás szindróma, illetve szepszis következtében elhunyt.

A második klinikai vizsgálat elvégzésére Vilniusban került sor 13 páciens transapicalis ínhúrpótlása kapcsán [25]. Az első vizsgálathoz hasonló kizáró tényezők szerepeltek a mútéti tervezésnél, valamint szintén csak a mitralis billentyű hátsó vitorlájának prolapsusa esetén végezték el a beavatkozást. Általánosan legalább két ínhúr beültetését tervezték betegenként. Minden beteg esetén a posterolateralis szívcsúcsi behatolást alkalmazták.

Intraoperatív sikert a 13 páciens közül 12 (92\%) esetben sikerült dokumentálni. Tíz betegnél jelentéktelen, 2 betegnél pedig elsőfokú mitralis elégtelenséggel végződött a beavatkozás. Egy esetben konvertálták a mútétet hagyományos mitralis plasztikára. Ez esetben effektív ínhúrpótlás nem volt lehetséges, ugyanis a vitorlán sérülések keletkeztek. A 12 primeren sikeres mütétből 6 páciensnél $(50 \%)$ két ínhúrt, 4 páciensnél (33\%) három ínhúrt, 2 páciensnél (17\%) pedig négy ínhúrt ültettek be.

A nyomon követés során 30 nap elteltével 1 betegnél találtak súlyos visszatérő billentyúelégtelenséget. Ez esetben a keskeny, relatív kedvezőtlen anatómiájú prolabáló szegmentumnál beültetett két ínhúrból egy kiszakadt. A többi 11 páciens 6 hónapos vizsgálata alkalmával legfeljebb másodfokú elégtelenség volt diagnosztizálható. Az összes betegből 3 esetén (23\%) jelentéktelen, 4 esetén (31\%) elsófokú, további 4 esetén (31\%) pedig másodfokú volt az insufficientia.

Átlagosan 113 perc alatt (80-150 perc) végezték el a beavatkozást. Maga az ínhúrbeültetés kevesebb mint 5 percet vett igénybe, visszahúzással és rögzítéssel együtt pedig mindez átlagosan 10 perc volt. A korábban említett konverzión kívül említésre méltó komplikáció nem lépett fel.

A harmadik vizsgálatot Pádua és Vilnius szakemberei végezték 62 , súlyos billentyưelégtelen betegnél [26]. Az indikációs kört kibővítették a mitralis billentyű hátsó vitorlája mellett az elülső, illetve mindkét vitorla prolapsusára is. Döntő többségben, pontosan 56 esetben (89\%), csak a hátsó vitorla volt érintett, 4 betegnél (6\%) csak az elülső, 3 esetben (5\%) pedig mindkét vitorla.

Ez a munkacsoport intraoperatív sikert minden páciens esetén elért, átlagosan 4 ínhúr pótlásával. A beültetett ínhúrok száma 2 és 7 között változott.

A mütét utáni 30. napon 10 betegnél (16\%) végzett vizsgálatok mutattak másodfokú mitralis elégtelenséget, akik közül 7 esetben az anulus vagy a vitorla meszesedését figyelték meg, illetve 2 elülső vitorla és 1 kombinált recidiváló prolapsus került leírásra. Visszatérő súlyos elégtelenség csak 8 páciens (13\%) esetén lépett fel. Ebből 2 esetben az elülső vitorla ínhúrjai szakadtak ki, és ezért konvencionális billentyücserét végeztek. Két betegnél az ínhúrok relatív megnyúlásával kellett számolni, és az ínhúrok meghúzásával sikeres rekonstrukciót hajtottak végre. A további pácienseknél a hátsó vitorlából kiszakadt ínhúrok által okozott insufficientiát konvencionális plasztikával tudták kezelni.

A mütéti idő átlagosan 130 perc volt, és a betegek $80 \%$-a az intenzív osztályon kevesebb mint 24 órát töltött. Átlagosan 3 órán keresztül volt szükség gépi lélegeztetésre, ám az utolsó 7 pácienst már a műtőben extubálták. A betegek átlagban 8 napot töltöttek kórházban. Intraoperatív konverzióra nem volt szükség. A beavatkozás alatt három beteg kivételével mindenki hemodinamikailag stabil volt. Két beteg esetében súlyos komplikációként szeptikus állapot lépett fel, egy páciens pedig myocardialis infarctust szenvedett el.

A negyedik, klinikai eredményeket közlő publikáció szintén a páduai centrum beavatkozásait összegzi 49 beteg esetében [27]. A feldolgozott esetek jelentős átfedést mutatnak a harmadikként részletezett vizsgálat adataival. A mitralis billentyư patológiáját illetően szintén hátsó, elülső, valamint kombinált prolapsusok kapcsán került elvégzésre az ínhúrpótlás.

Intraoperatív sikert minden beteg beavatkozásánál elértek legalább 3 ínhúr beültetésével.

A három hónapos utánkövetés során minimális elégtelenség 16 beteg $(33,4 \%)$, elsőfokú 15 beteg $(31,2 \%)$, másodfokú 12 beteg (25\%) esetében volt diagnosztizálható. Súlyos insufficientia mindössze 5 esetben $(10,4 \%)$ újult ki az elülső vitorla natív ínhúrjainak szakadása kapcsán. Ezen esetek közül 1 páciens újabb mütétje a súlyos kísérő betegségek miatt nem volt lehetséges, azonban négy páciens sikeres reoperációjára került sor.

A sebészi beavatkozások átlagban 120 percig tartottak, és 2 órás gépi lélegeztetéssel kellett számolni. A betegek 43\%-át közvetlenül a mútét után extubálták. Az átlagos kórházi tartózkodás 7 nap volt. Mindössze 1 szeptikus állapot és 1 myocardialis infarctus került leírásra, az összhalálozás nem haladta meg a $2 \%$-ot.

\section{Megbeszélés}

Az ismertetett klinikai vizsgálatok ugyan a módszer újdonsága miatt csak a rövid távú eredményekről tudnak beszámolni, a leírt, lényegében 100\%-os intraoperatív sikerarány mégis nagyon ígéretes [26, 27]. A következő évek során bizonyára további lendületes fejlődésre számíthatunk ezen innovatív módszer finomítása érdekében.

Az organikus mitralisbillentyü-elégtelenség esetén felállítandó mútéti indikáció kapcsán korábban meghatározó szerepet kaptak a betegek panaszai. Az egyre kifinomultabb vizsgálómódszerek és egyre tágabb kórélettani ismeretek a súlyos elégtelenséggel rendelkező patológiás billentyúk korai diagnosztikáját és kezelését teszik lehetővé. Így a szívben fokozatosan létrejövő, adott esetben akár irreverzibilis, mitralis insufficientia okozta patofizio- 
lógiai változásokat, többek között a bal kamrai pumpafunkció romlását, a korai billentyúplasztikával meg lehet előzni. A manapság sok esetben alkalmazott rigid és szemirigid gyürűk beültetésével végzett konvencionális anuloplasztikák során az anulus természetes struktúrája megbomlik. A transapicalis ínhúrpótlás azonban visszaadja a vitorlák fiziológiás mozgásának lehetőségét, továbbá megőrzi a bal kamra és a mitralis anulus háromdimenziós dinamikus egyensúlyát [26]. Az eddigi transapicalis ínhúrpótlással kapcsolatos vizsgálatokat elsősorban kisebb kockázatú és fiatalabb páciensek körében végezték. Természetesen lehetnek a jövőben ezek a kevés társbetegséggel rendelkező páciensek továbbra is a beavatkozás célcsoportja, azonban a módszer további fejlődésével megoldást jelenthet akár a multimorbid populáció által támasztott kihívásokra is [25].

A beültetett ínhúrok számával nőtt a sikeres beavatkozások száma. Ebben az esetben ugyanis megoszlik a terhelés a több ínhúr által visszahúzott prolabáló vitorlaszegmentum átöltött pontjain. Kezdetben a keskeny prolapsusok részesültek előnyben a mütéti indikáció felállításánál, azonban ezen patológiás billentyưk kezelése technikailag jelentősen nehezebbnek bizonyult, illetve tartós eredményt elérni is nagyobb kihívást jelentett. A vitorla széli részének megragadása sokkal könnyebbnek mutatkozott például a hátsó vitorla P2 vagy P3 szegmentumának széles prolapsusa esetén, és az ideális mútéti eredmények is ekkor születtek. A metszési pont korrigálása a klasszikus értelemben vett szívcsúcstól 2-4 cm-rel posterolateralis irányba tovább javította a beavatkozások eredményességét. A hátsó vitorlára nehezedő mechanikus terhelés szignifikánsan csökkenthető így, ugyanis ezek az ínhúrok rövidebbek és hosszanti tengelyük azonos a natív ínhúrokéval [25]. A beültetett ínhúrok rupturája nagyobb számban történt az elülső vitorla esetében, ezért ez esetben sikeresebben alkalmazható behatolási pont keresése szükséges. A mütét utáni korai időszakban a mesterséges ínhúrok relatív megnyúlása a bal kamrai remodelláció hatására következhet be a volumenterhelés megszünése miatt, és az ínhúrok utólagos meghúzása az eddigi tapasztalatok szerint megoldást jelenthet [26].

Igen fontos előnyként említendő meg az a tény is, hogy a szívcsúcsi metszés által okozott összenövések nem nehezítik meg jelentősen az esetleges konvencionális billentyüplasztika mint reoperáció során a szív feltárását. A nem kielégítő mütéti eredmény konvencionális korrekciója továbbra is intakt situs mellett lehetséges [27].

Várhatóan a korábbi tapasztalatokat integráló tanulmányok továbbra is egyre precízebben kivitelezett és ugyanakkor hosszú távon is eredményesebb beavatkozásokról fognak beszámolni, ugyanis az eredmények szempontjából elemi jelentőséggel bír az optimális betegszelekció, valamint az operatőr és az echokardiográfiás szakember egyre bővülő tapasztalata [24].
Anyagi támogatás: A közlemény megírása, illetve a kapcsolódó kutatómunka anyagi támogatásban nem részesült.

Szerzői munkamegosztás: R. T., G. B.: A cikk koncepciójának kialakítása, irodalomkutatás, a kézirat megszövegezése. J. G., G. K.: A kézirat megszövegezése. A cikk végleges változatát valamennyi szerző elolvasta és jóváhagyta.

Érdekeltségek: A szerzőknek nincsenek érdekeltségeik.

\section{Irodalom}

[1] Adams, D. H., Anyanwu, A. C.: Seeking a higher standard for degenerative mitral valve repair: begin with etiology. J. Thorac. Cardiovasc. Surg., 2008, 136(3), 551-556.

[2] Adams, D. H., Rosenhek, R., Falk, V.: Degenerative mitral valve regurgitation: best practice revolution. Eur. Heart J., 2010, 31(16), 1958-1966.

[3] Chiappini, B., Gregorini, R., De Remigis, F., et al.: Echocardiographic assessment of mitral valve morphology and performance after triangular resection of the prolapsing posterior leaflet for degenerative myxomatous disease. Interact. Cardiovasc. Thorac. Surg., 2009, 9(2), 287-290.

[4] Grisoli, D., Chan, V., Tran, A., et al.: Frequency and surgical management of complex posterior leaflet prolapse of the mitral valve. J. Heart Valve Dis., 2010, 19(5), 568-575.

[5] Glower, D. D., Kar, S., Trento, A., et al.: Percutaneous mitral valve repair for mitral regurgitation in high-risk patients: results of the EVEREST II study. J. Am. Coll. Cardiol., 2014, 64(2), 172-181.

[6] Ibrahim, M., Rao, C., Savvopoulou, M., et al.: Outcomes of mitral valve repair using artificial chordae. Eur. J. Cardiothorac. Surg., 2014, 45(4), 593-601.

[7] Carpentier, A.: Cardiac valve surgery - the "French correction". J. Thorac. Cardiovasc. Surg., 1983, 86(3), 323-337.

[8] Perier, P., Hohenberger, W., Lakew, F., et al.: Toward a new paradigm for the reconstruction of posterior leaflet prolapse: midterm results of the "respect rather than resect" approach. Ann. Thorac. Surg., 2008, 86(3), 718-725.

[9] Seeburger, J., Falk, V., Borger, M. A., et al.: Chordae replacement versus resection for repair of isolated posterior mitral leaflet prolapse: à ègalité. Ann. Thorac. Surg., 2009, 87(6), 1715-1720.

[10] Davierwala, P. M., Seeburger, J., Pfannmueller, B., et al.: Minimally invasive mitral valve surgery: "The Leipzig experience". Ann. Cardiothorac. Surg., 2013, 2(6), 744-750.

[11] Ruttkay, T., Baksa, G., Götte, J., et al.: Comparative endoscopic anatomic description of the mitral valvular complex: a cadaveric study. Thorac. Cardiovasc. Surg., 2015, 63(3), 231-237.

[12] Ruttkay, T., Czesla, M., Nagy, H., et al.: Experimental transapical endoscopic ventricular visualization and mitral repair. Thorac. Cardiovasc. Surg., 2015, 63(3), 238-242.

[13] Walther, T., Dewey, T., Borger, M. A., et al.: Transapical aortic valve implantation: step by step. Ann. Thorac. Surg., 2009, $87(1), 276-283$.

[14] Colli, A., Zucchetta, F., Torregrossa, G., et al.: Transapical offpump mitral valve repair with Neochord Implantation (TOPMINI): step-by-step guide. Ann. Cardiothorac. Surg., 2015, 4(3), 295-297.

[15] Pittarello, D., Colli, A., Falasco, G., et al.: Transesophageal echocardiogaphy in NeoChord procedure. Ann. Card. Anaesth., $2015,18(2), 191-197$

[16] Bajona, P., Katz, W. E., Daly, R. C., et al.: Beating-heart, offpump mitral valve repair by implantation of artificial chordae tendineae: an acute in vivo animal study. J. Thorac. Cardiovasc. Surg., 2009, 137(1), 188-193. 
[17] Seeburger, J., Leontjev, S., Neumuth, M., et al.: Trans-apical beating-heart implantation of neo-chordae to mitral valve leaflets: results of an acute animal study. Eur. J. Cardiothorac. Surg., $2012,41(1), 173-176$

[18] Jensen, H., Jensen, M. O., Waziri, F., et al.: Transapical neochord implantation: is tension of artificial chordae tendineae dependent on the insertion site? J. Thorac. Cardiovasc. Surg., 2014, 148(1), 138-143.

[19] Seeburger, J., Borger, M. A., Tschernich, H., et al.: Transapical beating heart mitral valve repair. Circ. Cardiovasc. Interv., 2010, $3(6), 611-612$

[20] Colli, A., Manzan, E., Zucchetta, F., et al.: Feasibility of anterior mitral leaflet flail repair with transapical beating-heart neochord implantation. JACC Cardiovasc. Interv., 2014, 7(11), 13201321

[21] Colli, A., Manzan, E., Fabio, F.Z., et al.: TEE-guided transapical beating-heart neochord implantation in mitral regurgitation. JACC Cardiovasc. Imaging, 2014, 7(3), 322-323.

[22] Colli, A., Bellu, R., Pittarello, D., et al.: Transapical off-pump Neochord implantation on bileaflet prolapse to treat severe mitral regurgitation. Interact. Cardiovasc. Thorac. Surg., 2015, $21(4), 554-556$.
[23] Merk, D. R., Aidietis, A., Seeburger, J.: Off-pump transapical neochordae implantation. Ann. Cardiothorac. Surg., 2015, 4(3), 293-294.

[24] Seeburger, J., Rinaldi, M., Nielsen, S. L., et al.: Off-pump transapical implantation of artificial neo-chordae to correct mitral regurgitation: the TACT Trial (Transapical Artificial Chordae Tendinae) proof of concept. J. Am. Coll. Cardiol., 2014, 63(9), 914-919.

[25] Rucinskas, K., Janusauskas, V., Zakarkaite, D., et al.: Off-pump transapical implantation of artificial chordae to correct mitral regurgitation: early results of a single-center experience. J. Thorac. Cardiovasc. Surg., 2014, 147(1), 95-99.

[26] Colli, A., Manzan, E., Rucinskas, K., et al.: Acute safety and efficacy of the NeoChord procedure. Interact. Cardiovasc. Thorac. Surg., 2015, 20(5), 575-580.

[27] Colli, A., Manzan, E., Zucchetta, F., et al.: Transapical off-pump mitral valve repair with Neochord implantation: Early clinical results. Int. J. Cardiol., 2015, 204, 23-28.

(Ruttkay Tamás dr., e-mail: ruttkaytom@gmail.com)

\section{FELHÍVÁS \\ folyóirat-referátumok beküldésére}

A Semmelweis Egyetem Továbbképző Központjának döntése értelmében

2016. január 1-jétöl folyamatosan orvos-továbbképzési pontokat kaphatnak a nemzetközi,

impaktfaktoros folyóiratokban megjelent közlemények rövid összefoglalásának, referátumának beküldöi.

Az Orvosi Hetilap hasábjain megjelenő és közlésre elfogadott referátum után 1 pont, félévente maximum

12 továbbképzési pont gyüjthető, amelyet félévente összesítve továbbitunk a továbbképzési központok felé.

Távoktatással szerzett pontokból évente legfeljebb 20 pont számitható be.

Aki továbbképzési pontot kiván gyüjteni, a referátum beküldésekor adja meg pecsétszámát.

Várjuk lelkes, továbbképzési pontokat gyüjteni kivánó referálóink jelentkezését!

\section{A referátum fejlécében az alábbi adatokat kérjük megadni:}

A cikk címe magyarul, zárójelben az angol cím

A szerző(k) neve (vezetéknév, a keresztnevet jelölő betü(k) - 3 szerzőig, háromnál több szerző esetén et al.), a levelező szerző neve, munkahelye és e-mail címe)

A folyóirat neve - a szokásos nemzetközi rövidítés szerint (PubMed), évszám, kötetszám, füzetszám, a cikk kezdő és utolsó oldalszáma

A referátumot elektronikus úton (Editorial Manager vagy e-mail: edit.budai@akademiai.hu) kérjük elküldeni. 